\title{
Bacterial antigens in synovial biopsy specimens in yersinia triggered reactive arthritis
}

\author{
R Merilahti-Palo, K-O Söderström, R Lahesmaa-Rantala, K Granfors, A Toivanen
}

\begin{abstract}
Non-viable structures of Yersinia enterocolitica 0:3 were shown at the site of inflammation within mononuclear cells in the synovial membrane of eight out of 10 patients with yersinia triggered reactive arthritis. An avidin-biotin-peroxidase complex method, with a rabbit antiserum specific for $Y$ enterocolitica 0:3, was used to visualise yersinia structures. All 13 control samples were negative except for one with non-specific mast cell staining. The findings emphasise the significance of foreign material in the initiation of synovitis in reactive arthritis.
\end{abstract}

Reactive arthritis has been defined as an inflammatory joint disease following an infection elsewhere in the body. ${ }^{1}$ The most common triggering agents include yersinia, chlamydia, salmonella, shigella, and campylobacter. It has been suggested that the triggering microbe persists after the initial infection in those patients developing arthritis, even though the stool cultures become negative for yersinia recovery shortly after the onset of infection. ${ }^{2-4}$ This hypothesis is based on a prolonged IgA response, ${ }^{5}$ which is directed against a multitude of yersinia antigens ${ }^{6}$ and the avidity of which increases with time. ${ }^{7}$ It is supported by demonstration of immune complexes containing yersinia antigens both in the circulation ${ }^{8}$ and in the synovial fluid ${ }^{9}$ of patients with yersinia triggered reactive arthritis. The most recent evidence for the bacterial persistence is the demonstration of yersinia antigens within polymorphonuclear leucocytes and, to some extent, in the mononuclear phagocytes in the synovial fluid of patients with reactive arthritis. ${ }^{10}$ Our work shows the presence of yersinia antigens at the site of inflammation, in the synovial membrane of patients with yersinia triggered reactive arthritis.

\section{Subjects and methods}

Twenty three patients with arthritis affecting the knee joint were studied. They were divided into four groups.

Group I consisted of 10 patients (Nos 1-10, table) with reactive arthritis triggered by Yersinia enterocolitica $\mathrm{O}: 3$. The diagnosis was based on serological (serotype specific enzyme linked immunosorbent assay (ELISA)), ${ }^{11}$ bacteriological, and clinical findings. All patients had a serum antibody response to the causative microorganism exceeding the mean response in healthy blood donors by at least 4 SD. Five patients excreted $Y$ enterocolitica $0: 3$ in the faeces at the time of diagnosis. All 10 patients were HLA-B27 positive. The period from onset of infection to the time of synovial biopsy was two weeks to five months.

Group II comprised two patients (Nos 11 and 12), who fulfilled the New York criteria for ankylosing spondylitis. They had had yersinia triggered reactive arthritis 14 and 17 years earlier respectively. Both patients still had antibodies against $Y$ enterocolitica $\mathrm{O}: 3$ and were HLA-B27 positive.

Group III comprised four patients (Nos 13-16) with reactive arthritis triggered by micro-organisms other than yersinia (one by Salmonella enteritidis, one by Campylobacter jejuni, one by Chlamydia trachomatis and Neisseria gonorrhoeae, and one by Clostridium difficile). All four patients were HLA-B27 positive.

Group IV consisted of seven patients (Nos 17-23) with other inflammatory joint diseases (four seronegative polyarthritis or oligoarthritis, two idiopathic knee effusions, and one gout). Two of these patients were HLA-B27 positive.

\section{HLA TYPING}

The HLA-B27 antigen on lymphocytes was assayed by cytotoxicity ${ }^{12}$ (Histognost-B27; Behring Institut, Marburg, West Germany).

\section{SYNOVIAL BIOPSY SPECIMENS}

Synovial tissue samples were taken from hydropic knee joints with a Parker-Pearson needle. ${ }^{13}$ The samples were immediately frozen, unfixed, into $5 \%$ gelatin blocks in liquid nitrogen and stored at $-70^{\circ} \mathrm{C}$ until sectioning.

BACTERIAL CULTURES FROM SYNOVIAL FLUID AND SYNOVIAL TISSUE

Nine of the 10 synovial fluid (Nos $1-4$ and 6-10) and seven of the 10 synovial tissue samples (Nos $2,3,6-10)$ from patients with yersinia triggered reactive arthritis were cultured for viable bacteria. Cultures were made by direct plating on blood and chocolate agar, as well as anaerobic brucella blood-agar supplemented with menadione and L-cysteine (MC-plate). The samples were also cultured after enrichment for one and three weeks in three different media: (a) brainheart infusion broth supplemented with $20 \%$ horse serum and $2 \%$ yeast extract $(\mathrm{BHI}+)$, which favours growth of several bacteria; $(b)$ $\mathrm{BHI}+$ supplemented with $20 \%$ glucose as a hypertonic medium to detect $\mathrm{L}$ forms of bacteria; (c) yeast extract-rose bengal broth, which favours growth of yersiniae. ${ }^{1415}$ 
IMMUNOSTAINING

The frozen synovial tissue blocks were sectioned with a Leitz microtome into 8-10 $\mu \mathrm{m}$ thick sections and fixed in cold acetone for 5 minutes. They were stained with the avidin-biotinperoxidase complex method ${ }^{16}$ (ABC kit; Vector Laboratories, Burlingame, California). For quenching of endogenous peroxidase activity the sections were incubated for $\mathbf{3 0}$ minutes in $0.3 \% \mathrm{H}_{2} \mathrm{O}_{2}$ in methanol. Non-specific binding was blocked by incubation in $1.35 \%$ normal goat serum in TRIS buffered saline for 30 minutes before staining. The primary antibodies were incubated overnight at $4^{\circ} \mathrm{C}$. A biotinylated, affinity purified, antirabbit IgG made in goat was used as a secondary antibody. All antibody dilutions were made in TRIS buffered saline containing $1 \%$ bovine albumin. The $A B C$ reagent contained avidin $\mathrm{DH}$ and biotinylated horseradish peroxidase $H$, and the reaction was completed with imidazole as substrate. Sections were counterstained with haematoxylin.

The degree of histological inflammation of the synovium was graded on a scale of $0_{-3}$, where 0 indicated no inflammation, 1 indicated the presence of 10-30 lymphocytes, 2 indicated the presence of 30-100 lymphocytes, and 3 that more than 100 lymphocytes were present in the section. The average size of the sections was about $3 \mathrm{~mm}^{2}$.

The sections were also stained with toluidine blue to detect mast cells, which have been reported to give positive staining with avidinperoxidase. ${ }^{17}$

The sections were examined blindly by two independent investigators; there were no discrepancies in their evaluations.
ANTISERUM USED FOR DETECTION OF BACTERIAL ANTIGENS

Rabbit antiserum against $Y$ enterocolitica $0: 3$ (640) was obtained by immunisation with live $Y$ enterocolitica $0: 3$ (4147/83) expressing plasmid encoded proteins. The specificity of the antiserum was verified by an ELISA inhibition test using $Y$ enterocolitica $0: 3(4147 / 83)$ and $0: 9$ (MY 79, B Niléhn, General Hospital, Malmö, Sweden) and $Y$ pseudotuberculosis I and II (clinical isolates), Escherichia coli (ATCC 25922), Klebsiella pneumoniae (ATCC 27736), Pseudomonas aeruginosa (ATCC 9721), and clinical isolates of Salmonella typhi, Brucella abortus, Proteus mirabilis, and Shigella sonnei. ${ }^{18}$ Only $Y$ enterocolitica $0: 3$ was able to induce a significant inhibition $(76 \%)$ of the antiserum $(640)$ in the inhibition test; the others induced $4 \%$ inhibition or less, indicating that the antiserum is highly specific for $Y$ enterocolitica $0: 3$.

The optimal $1 / 2000$ dilution for the antiserum (640) was determined by immunofluorescence with whole $Y$ enterocolitica $0: 3$ and by $A B C$ staining of spleen sections from a Lewis rat infected intravenously with live $Y$ enterocolitica O:3 one day before it was killed. The spleen sections contained positively stained mononuclear cells, and these sections were used as positive control.

As controls the preimmune serum from the same rabbit as well as the antiserum (640) after repeated absorptions with $Y$ enterocolitica $0: 3$ were used.

\section{Results}

The synovial biopsy samples showed similar histological signs of non-specific synovitis. The

Patient profiles and results of avidin-biotin-peroxidase complex staining of synovial biopsy specimens with rabbit antiserum (640) specific for Yersinia enterocolitica $O: 3$

\begin{tabular}{|c|c|c|c|c|c|c|c|c|c|c|c|c|c|}
\hline \multirow{2}{*}{$\begin{array}{l}\text { Patient } \\
\text { No }\end{array}$} & \multirow[t]{2}{*}{$\begin{array}{l}\text { Age } \\
\text { (years) }\end{array}$} & \multirow[t]{2}{*}{ Sex } & \multirow[t]{2}{*}{ Diagnosis } & \multirow{2}{*}{$\begin{array}{l}\text { Stool } \\
\text { culture* }\end{array}$} & \multicolumn{3}{|c|}{$\begin{array}{l}\text { Serum antibodies to } \\
Y \text { enterocolitica } O: 3 t\end{array}$} & \multirow{2}{*}{$\begin{array}{l}\text { Time } \\
\text { from onset } \\
\text { of disease } \\
\text { (weeks)f }\end{array}$} & \multirow[t]{2}{*}{$H L A-B 27$} & \multicolumn{3}{|c|}{ Positive with antiserum 640} & \multirow{2}{*}{$\begin{array}{l}\text { Degree of } \\
\text { inflammation } 5\end{array}$} \\
\hline & & & & & $\overline{I g M}$ & $I g G$ & $I g A$ & & & Unabsorbed & Absorbed & Preimmune & \\
\hline $\begin{array}{r}1 \\
2 \\
3 \\
4 \\
5 \\
6 \\
7 \\
8 \\
9 \\
10\end{array}$ & $\begin{array}{l}17 \\
37 \\
28 \\
33 \\
25 \\
41 \\
18 \\
50 \\
22 \\
64\end{array}$ & $\begin{array}{l}\mathbf{M} \\
\mathbf{M} \\
\mathbf{M} \\
\mathbf{M} \\
\mathbf{M} \\
\mathbf{M} \\
\mathbf{M} \\
\mathbf{F} \\
\mathbf{M} \\
\mathbf{F}\end{array}$ & $\begin{array}{l}\text { Reactive arthritis } \\
\text { Reactive arthritis } \\
\text { Reactive arthritis } \\
\text { Reactive arthritis } \\
\text { Reactive arthritis } \\
\text { Reactive arthritis } \\
\text { Reactive arthritis } \\
\text { Reactive arthritis } \\
\text { Reactive arthritis } \\
\text { Reactive arthritis }\end{array}$ & $\begin{array}{l}\bar{Y} \text { ent } 0: 3 \\
Y \text { ent } \mathrm{O}: 3 \\
Y \text { ent } \mathrm{O}: 3 \\
\bar{Y}_{\text {ent }} \mathrm{O}: 3 \\
Y \text { ent } \mathrm{O}: 3 \\
\overline{\mathrm{ND}} \\
-\end{array}$ & $\begin{array}{l}+++ \\
+++ \\
+++ \\
+++ \\
+++ \\
+ \\
+++ \\
+ \\
+++ \\
+++\end{array}$ & $\begin{array}{l}+++ \\
+++ \\
++ \\
+++ \\
+++ \\
+ \\
++ \\
++ \\
+++ \\
+++\end{array}$ & $\begin{array}{l}+++ \\
+++ \\
+ \\
+++ \\
+++ \\
++ \\
+++ \\
++ \\
+++ \\
++\end{array}$ & $\begin{array}{l}3 \\
3 \\
5 \\
2 \\
6 \\
6 \\
7 \\
2 \\
2 \\
3 \\
9\end{array}$ & $\begin{array}{l}+ \\
+ \\
+ \\
+ \\
+ \\
+ \\
+ \\
+ \\
+ \\
+\end{array}$ & $\begin{array}{l}+ \\
+ \\
+ \\
- \\
+ \\
+ \\
+ \\
+ \\
+ \\
+\end{array}$ & $\begin{array}{l}- \\
\overline{-} \\
\overline{-} \\
\overline{-} \\
\overline{-} \\
\overline{-}\end{array}$ & $\begin{array}{l}- \\
- \\
- \\
- \\
- \\
- \\
- \\
-\end{array}$ & $\begin{array}{l}3 \\
3 \\
2 \\
0 \\
2 \\
2 \\
2 \\
3 \\
3 \\
1\end{array}$ \\
\hline $\begin{array}{l}11 \\
12\end{array}$ & $\begin{array}{l}52 \\
32\end{array}$ & $\underset{\mathbf{F}}{\mathbf{M}}$ & $\begin{array}{l}\text { Ankylosing spondylitis } \\
\text { Ankylosing spondylitis }\end{array}$ & ND & $\overline{-}$ & $\begin{array}{l}++ \\
+\end{array}$ & $\begin{array}{l}+ \\
+\end{array}$ & $\begin{array}{l}17 \text { yrs } \\
14 \text { yrs }\end{array}$ & $\begin{array}{l}+ \\
+\end{array}$ & $\begin{array}{l}- \\
-\end{array}$ & $\begin{array}{l}- \\
-\end{array}$ & $\begin{array}{l}- \\
-\end{array}$ & $\begin{array}{l}3 \\
3\end{array}$ \\
\hline $\begin{array}{l}13 \\
14 \\
15\end{array}$ & $\begin{array}{l}23 \\
28 \\
26\end{array}$ & $\begin{array}{l}\mathbf{F} \\
\mathbf{M} \\
\mathbf{M}\end{array}$ & $\begin{array}{l}\text { Reactive arthritis } \\
\text { Reactive arthritis } \\
\text { Reactive arthritis }\end{array}$ & $\begin{array}{l}S \text { enterit } \\
C \text { jejuni } \\
\text { Chl trachom } \\
N \text { gonorh }\end{array}$ & $\begin{array}{l}- \\
-\end{array}$ & $\begin{array}{l}- \\
+ \\
-\end{array}$ & $\begin{array}{l}\overline{+} \\
\overline{-}\end{array}$ & $\begin{array}{l}2 \\
5 \\
7 \\
\operatorname{mos}\end{array}$ & $\begin{array}{l}+ \\
+ \\
+\end{array}$ & $\begin{array}{l}- \\
\overline{-}\end{array}$ & $\begin{array}{l}- \\
-\end{array}$ & $\begin{array}{l}- \\
-\end{array}$ & $\begin{array}{l}2 \\
1 \\
0\end{array}$ \\
\hline 16 & 27 & $\mathbf{F}$ & Reactive arthritis & $C l$ difficile & - & - & - & 2 & + & - & - & - & 1 \\
\hline $\begin{array}{l}17 \\
18 \\
19 \\
20 \\
21 \\
22 \\
23\end{array}$ & $\begin{array}{l}26 \\
74 \\
54 \\
71 \\
39 \\
32 \\
46\end{array}$ & $\begin{array}{l}\mathbf{M} \\
\mathbf{M} \\
\mathbf{F} \\
\mathbf{M} \\
\mathbf{M} \\
\mathbf{M} \\
\mathbf{M}\end{array}$ & $\begin{array}{l}\text { Seroneg. oligoarthritis } \\
\text { Seroneg. polyarthritis } \\
\text { Seroneg. oligoarthritis } \\
\text { Seroneg. polyarthritis } \\
\text { Idiopathic knee effusion } \\
\text { Idiopathic knee effusion } \\
\text { Gout }\end{array}$ & $\begin{array}{l}\bar{Z} \\
\bar{Z} \\
\text { ND } \\
=\end{array}$ & $\begin{array}{l}- \\
\overline{-} \\
- \\
- \\
\overline{-}\end{array}$ & $\begin{array}{l}\bar{z} \\
\bar{z} \\
\bar{z} \\
\bar{z}\end{array}$ & $\begin{array}{l}\bar{z} \\
\overline{-} \\
\bar{z} \\
\overline{-}\end{array}$ & $\begin{array}{l}3 \\
3 \\
7 \\
7 \\
2 \\
2 \\
6 \\
3 \\
1\end{array}$ & $\begin{array}{l}\overline{+} \\
+ \\
\overline{+} \\
\overline{-} \\
\overline{-}\end{array}$ & $\begin{array}{l}- \\
\overline{-} \\
\overline{-} \\
\overline{+} \\
-\end{array}$ & $\begin{array}{l}\overline{-} \\
\overline{-} \\
\overline{-} \\
\overline{+}\end{array}$ & $\begin{array}{l}\overline{-} \\
\overline{-} \\
\overline{-} \\
\overline{+} \\
-\end{array}$ & $\begin{array}{l}1 \\
3 \\
1 \\
1 \\
0 \\
1 \\
1\end{array}$ \\
\hline
\end{tabular}

*Y ent=Yersinia enterocolitica; $S$ enterit $=$ Salmonella enteritidis; $C$ jejuni=Campylobacter jejuni; $C h l$ trachom=Chlamydia trachomatis; $N$ gonorrh=Neisseria gonorrhoeae; Cl difficile $=$ Clostridium difficile.

$t+$ indicates an increase of antibodies exceeding the mean value for 100 healthy contròls by 2 SD, ++ by 4 SD, and +++ by 6 SD. Weeks unless specified otherwise. 
lining cell layers were thickened, and there was mild to moderate vascular proliferation and subsynovial infiltration of inflammatory cells. The inflammatory cells in all samples were mainly lymphocytes. In most samples the number of polymorphonuclear leucocytes was low, as was the number of plasma cells.

Positively stained cells were noted in the synovium of eight out of the 10 patients (Nos 1-10, table) with yersinia triggered reactive arthritis when $Y$ enterocolitica $0: 3$ specific antiserum (640) was used. The staining was seen in the cytoplasm of large mononuclear cells as a granular pattern. The positively stained cells were scattered diffusely, deep in the subsynovium (figure). No positively stained cells were detected in the lining cell layers. The number of positively stained cells varied from six to 20 per tissue section. One of the two patients with negative $A B C$ staining had very few, if any, inflammatory cells in the synovial biopsy specimen (No 4). Both the absorbed antiserum and the preimmune serum yielded negative staining results for all 10 patients.
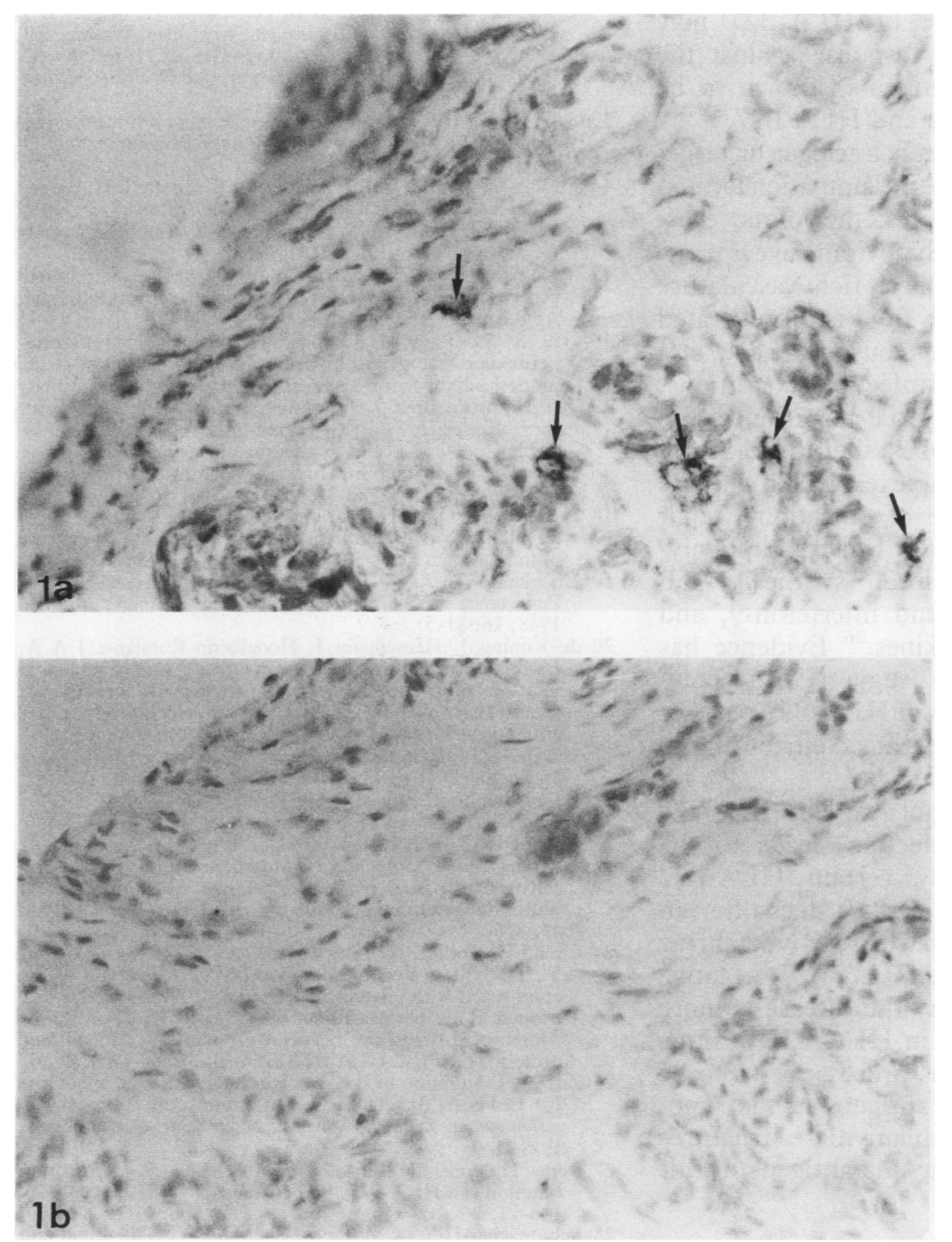

Avidin-biotin-peroxidase complex staining of two frozen sections of the synovium from a patient with yersinia triggered reactive arthritis. (a) Yersinia specific rabbit antiserum (640) and $(b)$ the same antiserum (640) absorbed with $Y$ enterocolitica $O: 3$ were applied. Positive granular cytoplasmic staining is seen in several large mononuclear cells beneath the synovial granular cytoplasmic staining is seen in several large mononuclear cells beneath the synovial
surface (a, arrows). With absorbed antiserum $(b)$ no corresponding staining was observed. Background staining is with haematoxylin.
Synovial samples of the two patients with ankylosing spondylitis and a previous history of yersinia reactive arthritis (Nos 11 and 12) were negative with all the antisera used. The four patients with reactive arthritis triggered by nonyersinia agents (Nos 13-16) were also negative with the three antisera.

In one of the group IV control patients (No 22) six to eight positively stained mononuclear cells were seen in the subsynovium when tested not only with the yersinia specific antiserum 640 , but also with the preimmune serum and the absorbed antiserum. These cells proved to be metachromatically stained mast cells when studied with toluidine blue staining. This HLAB27 negative patient was a 32 year old woman with idiopathic knee effusion. The knee effusion was treated successfully with intra-articular corticosteroid. The other patients in group IV (Nos 17-21, 23) showed no staining with any of the three sera. In the 10 synovial samples from the patients with yersinia triggered reactive arthritis no metachromatically stained cells were found with toluidine blue staining. All bacterial cultures were negative, from not only the synovial fluids, but also from the synovial tissue samples cultured.

\section{Discussion}

In this study we have shown the presence of cells containing yersinia antigens in the synovial membrane of eight of 10 patients with yersinia reactive arthritis. Both synovial fluid and synovial tissue were cultured for viable microorganisms. The cultures included prolonged enrichment in three different media selectively favouring the growth of yersiniae, including the L forms. With these procedures, even minimal amounts of live yersiniae, if present, should have been detected. All cultures were negative, suggesting that the bacterial structures found by $A B C$ staining were in a non-viable form. One control patient had positively stained cells in the synovial tissue. These cells, however, were also stained with the control sera, including the preimmune and the absorbed antiserum, illustrating the non-specific nature of the binding in this particular case. Avidin has been reported to bind to mast cells ${ }^{17}$ and the positively stained cells proved to be mast cells, when examined by toluidine blue staining.

Our findings prove the presence of bacterial structures at the site of inflammation, the synovial membrane, and emphasise the significance of foreign material in the initiation of synovitis. It remains unclear whether the bacterial antigens are transported into the synovium in the form of degraded bacterial products, in the form of immune complexes, or within cells. The bacterial antigens might possibly derive from the gut region, which would explain the persisting IgA response so common in reactive arthritis. Yersinia bacteria have recently been shown in the intestinal mucosa and adjacent lymph nodes of patients with acute and chronic $Y$ enterocolitica infection. ${ }^{19} 20 \mathrm{It}$ seems attractive to speculate that bacterial products are trapped by circulating polymorphonuclear and mononuclear cells, which 
then migrate through the vascular endothelium into the synovial membrane.

At the initial phase of synovitis polymorphonuclear cells predominate in the synovial fluid, to be replaced later by mononuclear cells. ${ }^{21}$ In our study the synovial inflammatory cells were almost exclusively mononuclear, accounting for detection of the yersinia antigens only within mononuclear cells.

Despite demonstration of bacterial structures at the site of inflammation, several factors in the initiation of synovitis still remain unexplained. ${ }^{22}$ For example, it is not known whether bacterial products localise in the same way in HLA-B27 negative subjects as was shown here in HLA-B27 positive ones. Even though HLA-B27 negative patients with yersiniosis may have joint symptoms, these symptoms are often mild and may pass as pure arthralgia without objectively verified synovitis. Thus it is feasible that the postinfectious inflammation becomes initially localised, regardless of HLA-B27 status, in strategic sites, especially in the synovium. This concept is supported by the demonstration of streptococcal cell wall components in the joints of rats resistant to streptococcal cell wall induced arthritis. $^{23}$ The presence of HLA-B27 may regulate the intensity of response against the target cells, owing to antigen(s) known to be shared by certain bacteria and HLA-B27. ${ }^{24} 25$

If the HLA-B27 antigen is a trigger or target of inflammation, why is the inflammation located preferentially at certain sites: the joints, eyes, and sometimes kidneys? Synovium, uveal tract, and renal glomeruli all have rich vasculature and mechanisms by which fluid is ultrafiltrated into the synovial space, aqueous of the eye, and urine respectively. In postinfectious conditions, or in the presence of bacterial persistence, the filtrate may contain microbes, their degradation products, or immune complexes, which become concentrated at the site of filtration. Their presence, particularly that of bacterial lipopolysaccharide, stimulates local synthesis and release of interleukin- 1 and interferon- $\gamma$, and other inflammatory cytokines. ${ }^{26}$ Evidence has also been presented to suggest that polymorphonuclear leucocytes of HLA-B27 positive subjects are hyperreactive, thus contributing to the severity of inflammation. ${ }^{27}$

Our reasoning does not explain why the initial antigenic load (infection) leads to the arthritic process in only certain HLA-B27 positive and negative subjects. It does offer an explanation, however, as to why reactive arthritis may also occur in some HLA-B27 negative subjects and, further, why the disease is more severe and more chronic in HLA-B27 positive subjects. Essential for this process seems to be the presence of bacterial antigens in the synovium, as shown for chlamydial structures previously ${ }^{28} 29$ and for yersinia antigens in this study.

We thank Professor P Toivanen, and Dr J Hill for critical review of the manuscript. This work was supported by the Sigrid Jusélius Foundation and the Farmos Research Foundation.

1 Ahvonen P, Sievers K, Aho K. Arthritis associated with
Yersinia enterocolitica intection. Acta Rheumatologica Scandinavica 1969; 15: 232-53.

2 Toivanen A, Granfors K, Lahesmaa-Rantala R, Leino R, Ståhlberg T, Vuento R. Pathogenesis of yersinia-triggered reactive arthritis: immunological, microbiological and clinical aspects. Immunol Rev 1985; 86: 47-70.

3 Toivanen A, Lahesmaa-Rantala R, Ståhlberg T H, MerilahtiPalo R, Granfors $K$. Do bacterial antigens persist in reactive arthritis? Clin Exp Rheumatol 1987; 5 (suppl 1): 25-7

4 Toivanen A, Toivanen P. Pathogenesis of reactive arthritis. In: Toivanen A, Toivanen $P$, eds. Reactive arthritis. Boca Raton, FL: CRC Press, 1988: 167-78.

5 Granfors $\mathrm{K}$, Toivanen A. IgA-anti-yersinia antibodies in yersinia triggered reactive arthritis. Ann Rheum Dis 1986; 45: 561-5.

6 Ståhlberg T H, Granfors K, Toivanen A. Immunoblot analysis of human IgM, IgG and IgA responses to plasmidencoded antigens of Yersinia enterocolitica serovar $03 . \mathcal{F}$ Med Microbiol 1987; 24: 157-63.

7 Lahesmaa-Rantala R, Lehtonen O P, Granfors K, Toivanen A. Avidity of anti-yersinia antibodies in yersiniosis patients with and without yersinia-triggered reactive arthritis. Arthritis Rheum 1987; 30: 1176-81.

8 Lahesmaa-Rantala R, Granfors K, Kekomäki R, Toivanen A. Circulating yersinia specific immune complexes after acute yersiniosis: a follow up study of patients with and without reactive arthritis. Ann Rheum Dis 1987; 46: 121-6.

9 Lahesmaa-Rantala R, Granfors K, Isomäki H, Toivanen A. Yersinia specific immune complexes in the synovial fluid of patients with yersinia triggered reactive arthritis. Ann Rheum Dis 1987; 46: $510-4$.

10 Granfors $\mathrm{K}$, Jalkanen $S$, von Essen $R$, et al. Yersinia antigens in synovial-fluid cells from patients with reactive arthritis. in synovial-fluid cells from patients

11 Granfors K. Measurement of immunoglobulin M (IgM), IgG and IgA antibodies against Yersinia enterocolitica by enzyme-linked immunosorbent assay: persistence of serum
antibodies during disease. $\mathcal{F}$ Clin Microbiol 1979; 9: 336-41.

12 Terasaki P I, Park M S. Microdroplet lymphocyte cytotoxicity test. In: Ray J G, Hare D B, Pedersen P D, Mullay D I, eds. NIAID manual of tissue typing techriques. Washington, DC: US Government Printing Office, 1976: 69-80. (Department of Health, Education, and Welfare publication No (NIH) 76-545.)

13 Schumacher H R Jr, Kulka J P. Needle biopsy of the synovial membrane: experience with the Parker-Pearson technic. $N$ Engl f Med 1972; 286: 416-9.

14 Phillips E, Nash P. Culture media. In: Lennette E H, Balows A, Hausler W J Jr, Shadomy J, eds. Manual of clinical microbiology. 4th ed. Washington, DC: American Society microbiology. 4th ed. Washington

15 Schiemann D A. Development of a two-step enrichment procedure for recovery of Yersinia enterocolitica from food. Appl Environ Microbiol 1982; 43: 14-27.

16 Hsu S M, Raine L, Fanger $H$. Use of avidin-biotinperoxidase complex (ABC) in immunoperoxidase techniques: a comparison between $A B C$ and unlabeled antibody (PAP) procedures. $\mathcal{J}$ Histochem Cytochem 1981; 29: 577-80.

17 Fritz P, Reiser H, Saal J G, Hadam M, Müller J, Wegner G. Analysis of mast cells in rheumatoid arthritis and osteoarthritis by an avidin-peroxidase staining. Virchows Arch [Cell Pathol] 1984; 47: 35-45.

18 Lahesmaa-Rantala R, Granfors K, Toivanen A. Detection of circulating yersinia-immunoglobulin complexes by enzyme immunoassay (EIA). F Immunol Methods 1986; 89: 191-9.

19 Hoogkamp-Korstanje J A A, de Koning J, Heesemann J. Persistence of Yersinia enterocolitica in man. Infection 1988; 16: 81-5.

20 de Koning J, Heesemann J, Hoogkamp-Korstanje J A A, Festen J J M, Houtman P A, van Oijen P L M. Yersinia in intestinal biopsy specimens from patients with seronegative spondyloarthropathy: correlation with specific serum IgA antibodies. F Infect Dis 1989; 159: 109-12.

21 Sharp J T. Reiter's syndrome (reactive arthritis). In: McCarthy D J, ed. Arthritis and allied conditions. 10th ed. Philadelphia: Lea and Febiger, 1985: 841-9.

22 Brewerton D. Causes of arthritis. Lancet 1988; ii: 1063-6.

23 Anderle S K, Allen J B, Wilder R L, Eisenberg R A, Cromartie W J, Schwab J H. Measurement of streptococcal cell wall in tissues of rats resistant or susceptible to cell wall-induced chronic erosive arthritis. Infect Immun 1985; 49: 836-7.

24 Chen J H, Kono D H, Yong Z, Park M S, Oldstone M M B A, Yu D T Y. A Yersinia pseudotuberculosis protein which
cross-reacts with HLA-B27. J I mmenol 1987; 139: 3003-11.

25 Toivanen P, Lahesmaa-Rantala R, Saario R, Skurnik M. Amino acid homology between yersinia outer membrane protein YOP1 and HLA-B27. Clin Rheumatol 1989; 8: 26. In: Lewis A, Ackerman N. Otterness I, eds. Advances in In: Lewis A, Ackerman N. Otterness I, eds. Advances in 1988: $1-9$.

27 Repo H, Leirisalo M, Koivuranta P, et al. Neutrophil function and HLA-B27. Br f Rheumatol 1983; 22 (suppl 2): 168-71.

28 Schumacher H R Jr, Magge S, Cherian P V, et al. Light and electron microscopic studies on the synovial membrane in Reiter's syndrome: immunocytochemical identification of chlamydial antigen in patients with early disease. Arthritis Rheum 1988; 31: 937-46.

29 Keat A, Thomas B, Dixey J, Osborn M, Sonnex C, TaylorRobinson D. Chlamydia trachomatis and reactive arthritis: the missing link. Lancet 1987; i: 72-4. 